\title{
Food Security in Venezuela: From Policies to Facts
}

\author{
Janet J. Rodríguez García ${ }^{1,2 *}$ \\ ${ }^{1}$ Department of Public Health Sciences, Central University of Venezuela, Caracas, Venezuela, ${ }^{2}$ Faculty of Medicine, School of \\ Nutrition and Dietetics, Central University of Venezuela, Caracas, Venezuela
}

The 1948 Universal Declaration of Human Rights, approved by The General Assembly of the United Nations, recognized the right to food as a Basic Human Right. Consequently, at the national level, programs, norms, and laws were decreed to promote the population's health and nutrition. The 1999 Venezuelan Constitution explicitly included, for the first time, the term "Food Security" in Article 305. Subsequently, the government approved various laws and guidelines to regulate the right to food of the population. However, despite such laws, the well-being of the population has not improved. According to the 2020 State of Food Security and Nutrition in the World (2020), between

\section{OPEN ACCESS}

Edited by:

Maria S. Tapia,

Academia de Ciencias Físicas,

Matemáticas y Naturales de

Venezuela, Venezuela

Reviewed by:

Ben Davies Tall,

United States Food and Drug

Administration, United States

Jennifer Bernal,

National University of

Colombia, Colombia

Andrés Jose Carmona,

Central University of

Venezuela, Venezuela

*Correspondence:

Janet J. Rodríguez García jarodsca@gmail.com

Specialty section:

This article was submitted to Agro-Food Safety,

a section of the journal

Frontiers in Sustainable Food Systems

Received: 15 October 2020 Accepted: 22 February 2021 Published: 19 March 2021

Citation:

Rodríguez García JJ (2021) Food Security in Venezuela: From Policies to

Front. Sustain. Food Syst. 5:617907.

doi: 10.3389/fsufs.2021.617907
2017 and 2019, the undernourishment prevalence amounted to 31.4\%. Also, reports from Caritas showed 14.4\% of Global Acute Malnutrition in children under 5 years of age, and $20 \%$ of children were at risk of acute malnutrition for the period April-June 2020. Other factors have influenced the actual Venezuelan food insecurity condition. The current severe economic and social crisis has led to a Complex Humanitarian Emergency. This work aimed to consider if decreeing many laws related to food and nutrition is not enough to reduce this scourge, or if there is any guarantee that the Food and Nutrition Security (FNS) of the people would improve.

Keywords: food, nutrition, food security, food policies, malnutrition, children, Venezuela

On December 10, 1948, 72 years ago, the right to food was recognized in the Universal Declaration of Human Rights by The General Assembly of the United Nations, Resolution 217 A (III).

Article 25 states: "Everyone has the right to an adequate standard of living that assures him, as well as his family, health and well-being, especially food..." (Naciones Unidas, 1948). Consequently at the national level, programs, norms, and laws were decreed to promote the population's health and nutrition. The 1999 Venezuelan Constitution, in its Article 305, explicitly included for the first time a Food Security statement, understood as the sufficient and stable availability of food at the national level, at all times, and its permanent access by the consuming public..." (República Bolivariana de Venezuela, 1999).

Subsequently, to favor the Right to Food of the Venezuelan people, various laws and regulations have been decreed. Table 1 describes the regulatory basis of food security in Venezuela. Despite these laws, and after the decree of the right to food in the Venezuelan Constitution, the country still has significant nutrition deficiencies. For instance, the State of Food Security and Nutrition in the World 2019 (FAO et al., 2019) reported that the prevalence of undernourishment increased by $21.2 \%$, rising to $31 \%$ the following year (FAO et al., 2020). According to Caritas, the Global Acute Malnutrition in children under 5 years of age (GAM) was 14.4\% in 2020 (Caritas de Venezuela, 2020). Moreover, the national report jointly issued, in December 2018, by the Bengoa Foundation, the Venezuelan Health Observatory, and the Agri-food Network of Venezuela, 33\% of children under 2 years of 
TABLE 1 | Regulatory basis for food security in Venezuela.

\begin{tabular}{|c|c|}
\hline Legal basis & Description \\
\hline $\begin{array}{l}\text { Constitution of the Bolivarian } \\
\text { Republic of Venezuela (República } \\
\text { Bolivariana de Venezuela, 1999) }\end{array}$ & $\begin{array}{l}\text { Article } \mathbf{3 0 5} \text { states: ".. the food security of the } \\
\text { population is guaranteed, understood as sufficient and } \\
\text { stable availability of food at the national level and timely } \\
\text { and permanent access to food by the population." }\end{array}$ \\
\hline $\begin{array}{l}\text { Venezuelan Land and Agrarian } \\
\text { Development Law, Decree №1.546 } \\
\text { Official Gazette Nº37,323 November } \\
\text { 13, } 2001 \text { (República Bolivariana de } \\
\text { Venezuela, 2001) }\end{array}$ & $\begin{array}{l}\text { Article } 1 \text { states: "The purpose is to establish the bases } \\
\text { of integral and sustainable rural development; } \\
\text { understood as the fundamental means for human } \\
\text { development and economic growth of the agricultural } \\
\text { sector within a fair distribution of wealth and strategic, } \\
\text { democratic and participatory planning, eliminating large } \\
\text { estates as a system contrary to justice, the general } \\
\text { interest and social peace in the field, ensuring } \\
\text { biodiversity, agri-food security and the effective } \\
\text { enforcement of environmental and agri-food protection } \\
\text { rights of present and future generations." }\end{array}$ \\
\hline
\end{tabular}

Law N`38.094 on Food for Workers, Article 1 states: "This is intended to regulate the benefit Extraordinary Official Gazette, December 27, 2004 (República Bolivariana de Venezuela, 2004)

Organic Law on Food Security and Sovereignty, Decree Law N6,071 Extraordinary Official Gazette July 31, 2008 (República Bolivariana de Venezuela, 2008)

Law of Attention to the Agrarian Sector Decree N`1,062 Official Gazette №40.440 June 25, 2014 (República Bolivariana de Venezuela, 2014b)

Creation of the National School Food Corporation, PAE Decree N`1,387 Official Gazette N40,538 November 11, 2014 (República Bolivariana de Venezuela, 2014a)
"For the construction of the Social State of justice and well-being, it is essential to guarantee Venezuelan citizens to have timely access to quality food preferably those produced in the country. Among the General Provisions of the Decree there is the declaration of public order, public utility and social interest of the activities that ensure the availability and timely access to safe, quality food for the population, with special mention of the possibility of proceeding to the compulsory acquisition of the assets related to such activities, upon payment of the fair price, without the need to obtain authorization from the National Assembly"

Article 1 states: "Debt restructuring and agricultural financing granted to beneficiaries whose items are strategic for the Food Security and Sovereignty that have meteorological, telluric, biological or physical agents"

Creation of the National Corporation for School Food, (CNAE PAE S.A. in its Spanish acronym) whose purpose is formulation, execution, and follow-up of plans for the production, acquisition, and distribution, of food destined for the basic education subsystem, as well as supervising the activities aimed to guarantee feeding and nutrition of children and adolescents of this system been damaged by causes attributable to weather,

\section{Validity Comments/considerations}

since

1999 It is the first time that Food Security is established as a right in Venezuela (República Bolivariana de Venezuela, 1999)

2001 This law has been the basis for the expropriation of lands with dramatic consequences on agricultural food production, more than 243 expropriations in 2016 (Ballesteros, 2017; Tapia et al., 2017; Universidad Católica Andrés Bello, 2020)

This law grants a food voucher to personnel who work for both the public and private sectors. The food voucher delivered at present is insufficient to cover the cost of food given the rampant hyperinflation in the country. (Landaeta-Jiménez et al., 2012; Tapia et al., 2017; Fundación Bengoa, 2018; Universidad Católica Andrés Bello, 2020). The cost of food in Venezuela exceeds by far the entire international poverty line of USD 1.90. The minimum monthly income is $800,000.00$ Sovereign Bolivares (400,000.00 minimum salary plus 400,000 socialist ticket basket) (República Bolivariana de Venezuela, 2020) equivalent to $1,71 \$$ and the cost of the food basket for workers is $131,723,370.17$ equivalent to \$188.31 for November 2020 (Centro de Documentación y Análisis para los Trabajadores, 2020)

2008 This law supported expropriations, and declared that all the steps in the productive chain were of "public utility" permitting the occupation of farms, enterprises, and productive units without due process. This law resulted in a dramatic fall of food production, food shortages, rural unemployment and higher prices for basic items of the diet. (Landaeta-Jiménez et al., 2012; Tapia et al., 2017; Fundación Bengoa, 2018; Universidad Católica Andrés Bello, 2020)

2014 This law was intended to favor the restructuring and financing of agricultural loans, however, the agricultura loan portfolio decreased considerably to less than $20,000,000$ dollars, from the $1,500,000,000$ dollars needed which translated into a decrease of national production and an increase in imports (Chourio, 2020)

2014 This program was designed without considering the infrastructure of the schools receiving the benefit with spaces not suitable for safe preparation of food. The limitations range from failure to comply with the infrastructure design to the lack of adequate equipment and services for the preparation and preservation of food, drinking water, gas, electricity and trained personnel, contravening the General Food Regulation (RGA) and Good Manufacturing Practices Gazette 36,081 (República de Venezuela, 1959, 1996, 1998; Landaeta-Jiménez et al., 2012; Tapia et al., 2017) 
TABLE 1 | Continued

\begin{tabular}{|c|c|}
\hline Legal basis & Description \\
\hline $\begin{array}{l}\text { Law of the Comprehensive National } \\
\text { Agrifood System, Decree №1,405 } \\
\text { Official Gazette № } 6150 \text { November } \\
\text { 18, } 2014 \text { (República Bolivariana de } \\
\text { Venezuela, 2014c) }\end{array}$ & $\begin{array}{l}\text { The National Superintendency of Agrifood Management } \\
\text { (Sunagro), entity attatched to the Ministry of Popular } \\
\text { Power for National Commerce, is created to keep a } \\
\text { national registry of natural and legal persons involved in } \\
\text { production, processing, distribution, import and export } \\
\text { of food, guaranteeing a fair and equitable distribution in } \\
\text { terms of national production in coordination with the } \\
\text { competent bodies. }\end{array}$ \\
\hline $\begin{array}{l}\text { Law of the Great AgroVenezuela } \\
\text { Mission, Decree N }{ }^{\circ} 1,409 \\
\text { Extraordinary Official Gazette Nº } 6151 \\
\text { November 18, } 2014 \text { (República } \\
\text { Bolivariana de Venezuela, 2014d) }\end{array}$ & $\begin{array}{l}\text { Article } 1 \text { states: "it aims to strengthen national food } \\
\text { production through scientific, technological, technical, } \\
\text { financial, logistical and organizational support to } \\
\text { producers, as well as to other actors and sectors of the } \\
\text { agrifood production chain, mainly in the areas of } \\
\text { produce, forestry, livestock, fishing and aquaculture to } \\
\text { guarantee the Food Security and Sovereignty of the } \\
\text { country" }\end{array}$ \\
\hline
\end{tabular}

Organic Law of Fair Prices Decree 600 Official Gazette № 40,340 January 23, 2014 (República Bolivariana de Venezuela, 2014e)

State of Exception and Economic Emergency Decree 2.323 Extraordinary Official Gazette N 6,227 May 13, 2016 (República Bolivariana de Venezuela, 2016)
Article 1 states: "it aims at the harmonious and sovereign development of the national economy, through the determination of fair prices of goods and services, the analysis of cost structures, the setting of the maximum percentage of profit and the effective control of economic and commercial activity, to protect the income of all citizens and especially the salary of workers. The law establishes administrative offenses, procedures and sanctions, economic crimes, their penalization and compensation for the damages inflicted on the consolidation of the productive socialist economic order."

\section{Validity Comments/considerations}

since

2014 Single Guides issued for mobilization and monitoring of all food produced and transformed in the country are required in fields and industries, determining where to dispatch the products affecting availability, timely reception and favoring corruption (Tapia et al., 2017; Fundación Bengoa, 2018; Chourio, 2020; Universidad Católica Andrés Bello, 2020)

2014 This law has not prevented the drop in Venezuelan food production, all agricultural sectors have been affected by lack of credit, expropriations of companies, currency devaluation, price controls and excessive regulations along each step of the value chain (Tapia et al., 2017; Fundación Bengoa, 2018; Chourio, 2020; Universidad Católica Andrés Bello, 2020). With a figure in the fall of national food production that exceeds $70 \%$, due to these factors (Blanco, 2020). The Gross Domestic Agricultural Product per capita decreased between 1998 and 2018 by $58.8 \%$ and between 2008 and 2018 by $62.8 \%$. According to the Confederation of Associations of Agricultural Producers of Venezuela (FEDEAGRO), between 2009 and 2018 the production of strategic agricultural commodities like rice decreased by $50.9 \%$ and corn in 55.9\% (Gutiérrez, 2019)

2014 In 2008, the Decree-Law on Agro- Price controls through modifications to the legal framework (decrees, Law of Costs and Fair Prices with their reforms) were intensified, and expanded in terms of the food included and applied to various links in the agro production chain (producer, wholesaler, factory, retailer), making it difficult for markets to function properly. The Venezuelan Chamber of the Food Industry (CAVIDEA) has identified over 200 laws, decrees or resolutions that affect and influence final prices. Neither the legal frameworks for these controls, nor the organizations that regulate their application, functioned properly. The price control effect was worsened by the strict exchange/currency control policies installed in 2003 along with high inflation. At present there is limited access to the national currency, exchange control has been eased, the economy moves in US dollars. Venezuela Food Inflation is projected to trend around $3300.00 \%$ in 2021 and $4900.00 \%$ in 2022 , according to some econometric models (Tapia et al., 2017; Chourio, 2020; FAO, 2020b; Trading Economics, 2021)

Article 2 states: "enables the executive to take appropriate exceptional and extraordinary measures to guarantee that citizens fully enjoy their rights, to preserve domestic order, ensure timely access to basic goods and services and mitigate the impact of natural circumstances that have affected power generation, access to food and other essentials. Among them: - Plan, coordinate and implement the urgent national and international procurement of goods or supplies essential to the health and feeding of citizens and upholding of basic services throughout the country, within the framework of trade or cooperation agreements - Allow the Bolivarian National Armed Forces and Local Supply and Distribution Committees (CLAPs) to intervene in the distribution and marketing of food and basic necessities."
2016 This decree facilitated the creation of food distribution committees (CLAPS) in which the communities themselves supply and distribute priority foods through a house-to-house delivery method. These foods were imported by expedited mechanisms while national food industries were compelled to destine $50 \%$ of their production to CLAPs Some problems emerged like distribution of low-quality products, little variety, and food imported without adequate and timely quality control without meeting current food safety and hygiene requirements (Tapia et al., 2017; Hernández et al., 2019; Universidad Católica Andrés Bello, 2020) 
TABLE 1 | Continued

\begin{tabular}{|c|c|c|c|}
\hline Legal basis & Description & $\begin{array}{c}\text { Validity } \\
\text { since }\end{array}$ & Comments/considerations \\
\hline $\begin{array}{l}\text { Constitutional Law of the Local } \\
\text { Committee of Supply and Production } \\
\text { CLAP Official Gazette N } 41.330 \\
\text { January 29, } 2018 \text { (República } \\
\text { Bolivariana de Venezuela, 2018) }\end{array}$ & $\begin{array}{l}\text { Article } 1 \text { states: Its purpose is to regulate the operation } \\
\text { of the Local Committee of Supply and Production } \\
\text { (CLAP), as well as the recognition of grassroots } \\
\text { organizations of People's Power, to ensure production, } \\
\text { supply, and distribution of food to guarantee the } \\
\text { independence, the social welfare of the People, the food } \\
\text { security, and the integral development of the Nation. }\end{array}$ & 2018 & $\begin{array}{l}\text { After the creation of the CLAP committees, they are } \\
\text { converted into a law with the main objective of dealing } \\
\text { with food shortages and hoarding, but the growing } \\
\text { economic crisis in the country made evident their } \\
\text { ineffectiveness. The distribution of CLAP bags or boxes } \\
\text { is very irregular in time, variety and quality of food (Tapia } \\
\text { et al., 2017; Universidad Católica Andrés Bello, 2020). } \\
\text { Also, corruption flourished in non-transparent } \\
\text { importation procedures facilitated by laxity in quality } \\
\text { control procedures, expedited importation mechanisms } \\
\text { favored by foreign currency assignments at preferential } \\
\text { rates for these operations (Hernández and Rivas, 2021) }\end{array}$ \\
\hline
\end{tabular}

age showed growth retardation when using the Size/Age indicator (Fundación Bengoa, 2018), that is, according to the data provided by these NGOs, that malnutrition is a foremost Public Health concern in Venezuela.

Likewise, other aspects of Food Security have been affected, such as the availability and access to food (Fundación Bengoa, 2018; Universidad Católica Andrés Bello, 2020), the quality of the diet, the adequate consumption of proteins of high biological value (Caritas de Venezuela, 2020), mainly as a consequence of the economic and social crisis not recognized by the executive branch of the country. The Gross Domestic Product fell by $70 \%$ between 2013 and 2019, and 79.3\% of Venezuelans have no sufficient income to cover the basic-food-basket (set of basicfoods necessary to ensure the nutrition of a family group of 5.2 members, consisting of eight subclasses of foods: meats and their preparations, fish and shellfish, cereals and their products, roots, and tubers, milk, cheese and eggs, fats and oils, fruits, and vegetables) (Landaeta-Jiménez et al., 2012; Tapia et al., 2017; Universidad Católica Andrés Bello, 2020).

Neither the food acquisition of Venezuelans, nor their nutritional-status, has improved even with the wide range of programs and laws enacted in the last 20 years. Recent statistics do not show any improvement in the malnutrition or undernourishment figures, much less in food-purchasing power since a 20 -fold increase of the minimum salary is required to cover the food basket (Tapia et al., 2017). Figures reported by Caritas Venezuela indicate that $57 \%$ of households were food-deprived (Caritas de Venezuela, 2020). These indicators demonstrate the extent of Venezuela's Complex Humanitarian Emergency (Tapia et al., 2017; Universidad Católica Andrés Bello, 2020). It means that decreeing one or more laws related to food and nutrition is not enough to reduce this scourge.

Venezuela requires cohesive, integrated, continuous, and progressive state-policies and laws rather than government initiatives that change according to political interests. Experts, statespersons, and health professionals should design the food policies. To properly set objectives and goals, an accurate diagnosis is required. The particular needs of each age-and-vulnerable-group should receive special consideration.
To further develop these Food and Nutrition Securitypolicies, a few aspects should be considered (FAO, 2012a): ample availability, physical and economic access, sustainability, and stability of the agri-food system, nutritional and cultural adequacy, and other considerations to promote the biological utilization of consumed food. Moreover, several bioethical considerations apply: equity, distributive justice, and beneficence (Beauchamp and Childress, 1994; Giovane Mendieta-Izquierdo, 2020).

These moral values, as well as the principles of the FNS, must be an essential part of any program in Nutritional Public Health so that they can be continuous, assessable, measurable, and adaptable, that is to say, that all the programs that are developed can be monitored, adjusted, and controlled.

Bioethical principles aim to protect the human dignity of man. The association of these principles with food security improves the design of food policies. Initiatives developed using these approaches are real, fair, and well-balanced without disparagement or discrimination of any age group. Table 2 includes several recommendations for improvement of food security in Venezuela based on the principles of the food security and bioethics.

In Venezuela, actual experience is to develop nutrition care programs that lack clear and precise objectives (Delgado and Herrera-Cuenca, 2019), with scope and goals that cannot be evaluated in a given period of time. They are usually developed as part of a policy plan, and subsequently forgotten or replaced by other faulty proposals following the same pattern.

Upon all these food insecurity problems, the country now faces the SARS-CoV-2, a highly aggressive Coronavirus that causes the Covid-19 pandemic, declared as such in March 2020. Limitations imposed because of Covid-19 further aggravate the delicate food situation in Venezuela.

The World Health Organization (WHO) has specified recommendations and guidelines to contain the virus spread. Among these are 14-day quarantine for suspected cases and isolation of cases confirmed; use of a face mask, hand-washing with soap and water, hand disinfection with alcoholic gels, thorough-domestic cleaning, and disinfection, as well as the maintenance of a $2 \mathrm{~m}$ physical-distancing. 
TABLE 2 | Recommendations for improvement of food security in Venezuela based on the principles of the food security and bioethics.

\begin{tabular}{|c|c|c|c|}
\hline Recommendation & FNS Principles & Bioethical principles & Impact \\
\hline $\begin{array}{l}\text { Adopt and invest on a multi-sectoral, } \\
\text { multi-stakeholder, integrated } \\
\text { approach to improve nutrition, like the } \\
\text { one fostered by SUN in order to } \\
\text { promote food systems sensible to } \\
\text { nutrition in the country. (Scaling Up } \\
\text { Nutrition, 2021) } \\
\text { `Is a movement that advocates a } \\
\text { multi-sector and multi-stakeholder } \\
\text { approach to improving nutrition by } \\
\text { promoting dialogue on food systems } \\
\text { and obtaining the results that are } \\
\text { needed. }\end{array}$ & $\begin{array}{l}\text { Nutrition-sensitive agriculture and } \\
\text { food systems to improve the } \\
\text { availability, accessibility, and } \\
\text { consumption of nutritious foods and } \\
\text { to protect hard-won gains in the fight } \\
\text { against all forms of malnutrition. }\end{array}$ & $\begin{array}{l}\text { Experts in food security should } \\
\text { promote ethical questions and define } \\
\text { food security values that impact } \\
\text { nutrition outcomes and the ethical } \\
\text { trade-offs between environmental } \\
\text { sustainability while meeting individual } \\
\text { dietary and nutritional needs. (Fanzo, } \\
\text { 2015) }\end{array}$ & $\begin{array}{l}\text { Food Security programs sensitive to } \\
\text { nutrition } \\
\text { Decrease of nutrition, inequities. } \\
\text { Provide for people's nutritional needs, } \\
\text { while contributing to sustainable } \\
\text { growth. } \\
\text { Decrease the prevalence of } \\
\text { undernourishment, and chronic } \\
\text { malnutrition } \\
\text { Improvement of the height/age } \\
\text { indicator } \\
\text { Decreased risk of short stature due to } \\
\text { malnutrition }\end{array}$ \\
\hline $\begin{array}{l}\text { Design of nutritional care programs, } \\
\text { based on the principles of FNS, } \\
\text { carried out by experts in Food and } \\
\text { Nutritional Security. } \\
\text { Diagnostic evaluation of the nutritional } \\
\text { situation in urban ( } 80 \% \text { of the } \\
\text { population) and rural communities. }\end{array}$ & $\begin{array}{l}\text { Know which population is at risk or in } \\
\text { frank nutritional deterioration and } \\
\text { which of the FSN principles are } \\
\text { affected would help to design } \\
\text { programs focused on improving the } \\
\text { main problems, according to each } \\
\text { age group. }\end{array}$ & $\begin{array}{l}\text { Beneficence is the relevant principle } \\
\text { in this recommendation since it is } \\
\text { necessary to benefit the entire } \\
\text { population at risk or in frank nutritional } \\
\text { deterioration, determining their needs. }\end{array}$ & $\begin{array}{l}\text { Have real-time figures of the } \\
\text { nutritional status of Venezuelan } \\
\text { children provided by official entities. } \\
\text { A real commitment of government } \\
\text { institutions to comply with designed } \\
\text { programs within the legal framework } \\
\text { established by them. }\end{array}$ \\
\hline $\begin{array}{l}\text { Define clear and measurable } \\
\text { nutritional goals }\end{array}$ & $\begin{array}{l}\text { By defining clear and measurable } \\
\text { nutritional objectives, it would be } \\
\text { possible to direct efforts in the right } \\
\text { direction allowing their modification }\end{array}$ & $\begin{array}{l}\text { The bioethical principle par excellence } \\
\text { would be distributive justice, to } \\
\text { protect all beneficiaries according to } \\
\text { the set objectives. }\end{array}$ & $\begin{array}{l}\text { Design of inclusive food security } \\
\text { programs for the entire population } \\
\text { without the need for a political or } \\
\text { government-related card }\end{array}$ \\
\hline
\end{tabular}

Execute programs designed according to the initial diagnosis, indicating the start date and date evaluation schedule to measure the effectiveness

Control and monitoring of all foods and nutritional designed programs.

Timely report of results of the programs executed.

Guarantee of continuity and stability of the food programs already established.

Expansion of Food Security programs to cover the entire population without discrimination by political reasons.

Timely publication of data on consumption, availability, and access to foods from government-managed-food programs. according to the results obtained during their execution

An initial diagnosis allows the FSN programs to be executed in a precise and oriented way to achieve the set objectives

All the principles benefit from the application of this recommendation. It diminishes the possibility to abandon programs for unknown causes.

Timely communication is essential to develop food security programs that are updated and consider all the principles.

Knowing how biological consumption and the nutritional adequacy of programs impact FNS principles will help to improve each program according to the results obtained while preventing the abandonment of successful programs.

Food security depends on the commitment to prevent hunger in all population groups

Reliable and timely publication of data on consumption, availability, and food access is of utmost importance to determine the impact of a program and select variables to update it according to the results of successive evaluations.
Equity is the bioethical principle that supports this recommendation to address the needs of each individual.

Distributive justice is highlighted in this recommendation since an unmonitored program cannot be adjusted and modified according to the needs of the target population.

All bioethical principles benefit from this recommendation, particularly transparency, by promoting adequate information to achieve the goals of executed programs.

All bioethical principles benefit from this recommendation. It is necessary to assist in a just and equitable way all the members of a population.

True social and distributive justice benefits ample coverage programs that do not discriminate for political, religious, or social reasons.

In this recommendation, a combination of bioethical principles contributes to the common good of the entire population.
Food Security programs sensitive to nutrition while contributing to sustainable growth.

ecrease the prevalence of malnutrition indicator

Decreased risk of short stature due to utrition by official entities. programs within the legal framework established by them. 
TABLE 2 | Continued

\begin{tabular}{|c|c|c|c|}
\hline Recommendation & FNS Principles & Bioethical principles & Impact \\
\hline $\begin{array}{l}\text { Improvement of the national health } \\
\text { system }\end{array}$ & $\begin{array}{l}\text { Improvement of the population's } \\
\text { health status begins with adequate } \\
\text { food and nutrition security, which is } \\
\text { also a constitutional right. }\end{array}$ & $\begin{array}{l}\text { The bioethical principle of } \\
\text { beneficence is universal and } \\
\text { inalienable; therefore, political or } \\
\text { religious factors should not condition } \\
\text { food security. }\end{array}$ & \\
\hline $\begin{array}{l}\text { Resurface and update of the National } \\
\text { Food Council to transform it into an } \\
\text { inclusive-normative-and-independent } \\
\text { organism. This way, it could supervise } \\
\text { national policies to eradicate } \\
\text { malnutrition and hunger. }\end{array}$ & $\begin{array}{l}\text { The integration of public and private } \\
\text { institutions that work for food security. }\end{array}$ & $\begin{array}{l}\text { Applying bioethical principles } \\
\text { promotes the highest ideal: the } \\
\text { eradication of malnutrition and } \\
\text { hunger. }\end{array}$ & \\
\hline
\end{tabular}

The asterisk is the link between the word SUN and the definition.

Venezuela rapidly imposed these measures. Confinement of the country started on March 13, 2020, after the first cases were confirmed. Quarantine measures required many adjustments, particularly in food collection, storage, distribution, and delivery, both to the general and vulnerable population groups to avoid the surging of nutrition problems.

The pandemic has increased food insecurity and poverty, as many people have lost their jobs and or have insufficient income to cover the basic food basket. The National Survey of Living Conditions (ENCOVI) surveyed the impact of COVID-19 on employment and income. Figures show that $43 \%$ of the surveyed households report the inability to work or have lost income (Universidad Católica Andrés Bello, 2020).

According to the World Food Program July-September-2019 survey (World Food Program, 2019), 7.9\% of the population (2.7 million) is in Severe Food Insecurity, and $24.4 \%$ (7 million) are in moderate Food Insecurity. These figures are previous to the onset of the pandemics. In addition, other factors contribute to aggravate the effects of confinement little availability of cash, shortage of gasoline, installation of police and military control posts and barricades and severely impact food security.

As shown by ENCOVI in its latest publication (March 2019March 2020), rampant inflation exceeds 3,365\% and $73.9 \%$ do not have enough income to cover the food basket in Venezuela. Rising unemployment figures in Venezuela are comparable to those of countries such as Nigeria, Chad, Congo, and Zimbabwe (Universidad Católica Andrés Bello, 2020).

Updated official figures on food availability, access, and consumption are not available. Therefore evaluation of pandemic-impact cannot be estimated. Different expert committees in Food and Nutritional Security (FNS) have declared that the Covid-19 pandemic will have severe

\section{REFERENCES}

Abuelafia, E., and Saboin, J. L. (2020). A Look to the Future for Venezuela. Country Department Andean Group. Inter-American Development Bank. Discussion Paper No. IDB-DP-798. Publications IADB. Available online at: https:// publications.iadb.org/publications/english/document/A-Look-to-the-Futurefor-Venezuela.pdf (accessed February 12, 2021).

Ballesteros, A. (2017). "Cuántas expropiaciones se han ejecutado durante el gobierno de Maduro” El Estímulo, 22 de agosto 2017. Available online at: repercussions on food security in the world (FAO, 2020b; FAO-CELAC, 2020; OXFAM, 2020), especially in countries that were already experiencing economic and social crises.

In Venezuela, multiple maladies (hyperinflation, unemployment, low wages, food and gasoline shortages, deficient public services) pave the current humanitarian crisis and forecast the nutrition and health problems assuredly prevalent shortly. Worrisome is the change in the eating pattern due to the intake of cheaper-starchy foods while sacrificing expensive high biological value proteins.

What has been missing is a strong political motivation to enforce the approved legislation. Unfortunately, government initiatives are short-sighted and aimed to strengthen the political grip on the population. For instance, Clap boxes reach their beneficiaries but do not satisfy their food and nutrition needs. The program to sell subsidized gasoline is very significant, but gas supply is scarce encouraging under-the-counter corrupt transactions (Abuelafia and Saboin, 2020). At present, there are at least 10 laws and programs which address food security issues. Nonetheless, acute malnutrition is rampant.

As sustained in this work, decreeing many laws related to food and nutrition is not enough to reduce hunger, malnutrition, inequity, etc. An attempt was made to demonstrate through the Venezuelan case, that States and the legal framework of a country are not always the guarantors the Food and Nutrition Security of the people, particularly if their design and enforcement disregards the advice of the health and nutrition experts.

\section{AUTHOR CONTRIBUTIONS}

The author confirms being the sole contributor of this work and has approved it for publication.

https://elestimulo.com/elinteres/cuantas-expropiaciones-se-han-ejecutadodurante-el-gobierno-de-maduro/ (accessed February 6, 2021).

Beauchamp, T. L., and Childress, J. F. (1994). Principles of Biomedical Ethics, 4th Edn. Oxford: Oxford University Press.

Blanco, D. (2020). "Caída de más de 70\% de la producción nacional revela que la soberanía alimentaria quedó en el pasado” El Carabobeño, 26 de Noviembre 2020. Available online at: https://www.el-carabobeno.com/caida-de-laproduccion-nacional-soberania-alimentaria-quedo-en-el-pasado/ (accessed February 12, 2021). 
Caritas de Venezuela (2020). Monitoreo Centinela de la Desnutrición Infantil y la Seguridad Alimentaria Familiar de los meses de Abril-Julio 2020. Available online at: http://caritasvenezuela.org/wp-content/uploads/2020/09/BoletinSAMAN_Caritas-Venezuela_Abril-Julio2020-r1_compressed.pdf (accessed September 15, 2020).

Centro de Documentación y Análisis para los Trabajadores (CENDA) (2020). Canasta Alimentaria de los Trabajadores. Noviembre 2020. Available online at: http://cenda.org.ve/fotos_not/pdf/CENDA.\%20RESUMEN\%20EJECUTIVO. \%20CAT\%20NOVIEMBRE\%202020WEB\%20com.Pdf (accessed February 12, 2021).

Chourio, J. (2020). "2020 ha sido el año más catastrófico en producción agrícola en Venezuela." El Diario, 22 de Octubre 2020. Available online at: https://eldiario. com/2020/10/22/produccion-agricola-2020-ano-mas-catastrofico/ (accessed January 24, 2021).

Delgado, A., and Herrera-Cuenca, M. (2019). El derecho a la alimentación en Venezuela bajo el enfoque de derechos. Cuadernos del Cendes, Año 36. $\mathrm{N}^{\circ} 100$ Tercera época Enero-April 2019, p. 57-80.

Fanzo, J. (2015). Ethical issues for human nutrition in the context of global food security and sustainable development. Glob. Food Secur. 7, 15-23. doi: 10.1016/j.gfs.2015.11.001

FAO (2012a). Ley Marco, Derecho a la Alimentación, Seguridad y Soberanía Alimentaria. XVIII Asamblea Ordinaria del Parlamento Latinoamericano, Panamá, 30 de Noviembre 2012.

FAO (2020b). Impacto del Covid 19 en la Seguridad Alimentaria y la Nutrición (SAN). Secretaría del GANESAN, Versión 1, 24 de marzo de 2020. Available online at: http://www.fao.org/fileadmin/templates/cfs/Docs1920/Chair/HLPE_ Spanish.pdf (accessed July 31, 2020).

FAO, FIDA, OMS, PMA y UNICEF (2020). El estado de la seguridad alimentaria y la nutrición en el mundo 2020. Transformación de los sistemas alimentarios para que promuevan dietas asequibles y saludables. Roma: FAO.

FAO, IFAD, UNICEF WFP and WHO (2019). The State of Food Security and Nutrition in the World 2019. Safeguarding Against Economic Slowdowns and Downturns. Rome: FAO.

FAO-CELAC (2020). Seguridad Alimentaria bajo la Pandemia de Covid-19. Informe preparado por FAO a solicitud de la Coordinación Nacional de la Presidencia Pro Témpore de México ante la CELAC, 2020. Available online at: http://www.fao.org/fileadmin/user_upload/rlc/docs/covid19/Boletin-FAOCELAC.pdf (accessed August 1, 2020).

Fundación Bengoa (2018). Observatorio Venezolano de la Salud (OVS) y la Red Agroalimentaria de Venezuela. Emergencia Humanitaria Compleja en Venezuela, Derecho a la Alimentación, Reporte Nacional, Diciembre 2018. Available on line at: http://www.tsj.gob.ve/es/web/tsj/gaceta-oficial (accessed January 6, 2021).

Giovane Mendieta-Izquierdo (2020). Juan María Cuevas-Silva. Bioética en Salud Pública. Universidad Militar Nueva Granada. Available online at: http://www. scielo.org.co/pdf/rlb/v17n2/1657-4702-rlb-17-02-00001.pdf (accessed January $6,2020)$.

Gutiérrez, A. (2019). La Situación Agroalimentaria en Venezuela. Hacia una Nueva Estrategia Revista Foro. 3, 31-52.

Hernández, C., and Rivas, T. (2021). Frontiers... Dismantling of Institutionalization and State Policies as Guarantors of Food Security in Venezuela. Food Safety Implications (in press). doi: 10.3389/fsufs.2021.623603

Hernández, P., Marcano, P., and Deniz, R., (2019). Evaluación del contenido nutricional de productos lácteos en programa de alimentación venezolano. Arch. Lat. Nutr. 69, 113-124.

Landaeta-Jiménez, M., Aliaga, C., Sifontes, Y., Herrera, M., Candela, Y., Delgado, A., et al. (2012). El Derecho a la Alimentación en Venezuela. Anales Venezolanos de Nutrición. 25, 73-84.

Naciones Unidas (1948). Carta internacional de los derechos humanos, 217 (III) Art 25, declaración universal de los derechos humanos 183 a, sesión plenaria, 10 de diciembre de.

OXFAM (2020). El virus del hambre: cómo el Coronavirus está agravando el hambre en un mundo hambriento. Nota informativa de OXFAM, 09 de julio 2020. Available online at: https://oxfamilibrary.openrepository.com/bitstream/ handle/10546/621023/mb-the-hunger-virus-090720-es.pdf (accessed August $1,2020)$.

República Bolivariana de Venezuela (1999). Constitución de la República Bolivariana de Venezuela, 305 1999. Gaceta Oficial No 5908. 19 de Febrero, 2009.
República Bolivariana de Venezuela (2001). Ley de Tierras y Desarrollo Agrario de Venezuela, Decreto 1.546, Gaceta Oficial No 37.323, 13 de Noviembre de 2.001. Available online at: http://www.tsj.gob.ve/es/web/tsj/gaceta-oficial (accessed January 22, 2021).

República Bolivariana de Venezuela (2004). Ley de Alimentación para los Trabajadores, Gaceta Oficial N ${ }^{\circ}$ 38.094, 27 de diciembre de 2004.

República Bolivariana de Venezuela (2008). Ley Orgánica de Seguridad y Soberanía Agroalimentaria, Decreto $\mathrm{N}^{\circ}$ 6.071, Gaceta Oficial Extraordinaria $\mathrm{N}^{\circ} 5889,31$ de Julio 2008.

República Bolivariana de Venezuela (2014a). Creación de la Corporación Nacional de Alimentación Escolar, PAE. Decreto $\mathrm{N}^{\circ}$ 1.387, Gaceta Oficial $\mathrm{N}^{\circ} 40.538$, 11 de noviembre de 2014. Available online at: http://www.tsj.gob.ve/es/web/tsj/ gaceta-oficial (accessed January 22, 2021).

República Bolivariana de Venezuela (2014b). Decreto con Rango, Valor y Fuerza de Ley de Atención al Sector Agrario, Decreto $\mathrm{N}^{\circ} 1.062$, Gaceta Oficial $\mathrm{N}^{\circ}$ 40.440, 25 de Junio de 2014. Available on line at: http://www.tsj.gob.ve/es/web/ tsj/gaceta-oficial (accessed January 22, 2021).

República Bolivariana de Venezuela (2014c). Decreto con Rango, Valor y Fuerza de Ley del Sistema Nacional Integral Agroalimentario, Decreto $\mathrm{N}^{\circ} 1.405$, Gaceta Oficial $\mathrm{N}^{\circ}$ 6150, 18 de Noviembre de 2014. Available on line at: http://www.tsj. gob.ve/es/web/tsj/gaceta- oficial (accessed January 22, 2021).

República Bolivariana de Venezuela (2014d). Decreto con Rango, Valor y Fuerza de Ley de la Gran Misión AgroVenezuela, Decreto $N^{\circ} 1.409$, Gaceta Oficial Extraordinaria $\mathrm{N}^{\circ}$ 6.151, 18 de Noviembre de 2014. Available online at: http:// www.tsj.gob.ve/es/web/tsj/gaceta-oficial (accessed January 22, 2021).

República Bolivariana de Venezuela (2014e). Decreto con Rango, Valor y Fuerza de Ley Orgánica de Precios Justos, Decreto 600, Gaceta Oficial No 40.340 de fecha 23 de enero de 2014. Available online at: http://www.tsj.gob.ve/es/web/ tsj/gaceta-oficial (accessed January 22, 2021).

República Bolivariana de Venezuela (2016). Estado de Excepción y Emergencia Económica. Decreto $\mathrm{N}^{\mathrm{o}}$ 2.323, Gaceta Oficial Extraordinaria $\mathrm{N}^{\mathrm{o}} 6.227$ de fecha 13 de Mayo de 2016. Available online at: http://www.tsj.gob.ve/es/web/tsj/ gaceta-oficial (accessed January 22, 2021)

República Bolivariana de Venezuela (2018). Ley Constitucional de los CLAP, sancionada por la Asamblea Nacional Constituyente. Gaceta Oficial No 41.330 , 29 de Enero de 2018. Available online at: http://www.tsj.gob.ve/es/web/tsj/ gaceta-oficial (accessed January 22, 2021).

República Bolivariana de Venezuela (2020). Presidencia de la República. Decreto $\mathrm{N}^{\circ} 4.193$, mediante el cual se incrementa el ingreso mínimo mensual y la protección social. Gaceta Oficial Extraordinaria $\mathrm{N}^{\circ} 6.532$ de fecha 27 de abril de 2020. Available online at: http://www.tsj.gob.ve/es/web/tsj/gaceta-oficial (accessed February 6, 2021).

República de Venezuela (1959). Reglamento General de Alimentos. Decreto $\mathrm{N}^{\circ}$ 525, Gaceta Oficial No 25.864, 16 de Enero 1959.

República de Venezuela (1996). Ministerio de Sanidad y Asistencia Social. Normas de Buenas Prácticas de Fabricación, Almacenamiento y Transporte de Alimentos para Consumo Humano. SG No 457-96, Gaceta Oficial No 36081. 07 de Noviembre 1996.

República de Venezuela (1998). Ministerio de Sanidad y Asistencia Social. Normas Sanitarias de Calidad del Agua Potable. SG N ${ }^{\circ}$ 018-98. Gaceta Oficial No 36.395. 13 de febrero 1998.

Scaling Up Nutrition (2021). Los Sistemas Alimentarios y la Nutrición. Available online at: https://scalingupnutrition.org/es/nutricion/los-sistemasalimentarios-y-la-nutricion/ (accessed February 12, 2021).

Tapia, M. S., Puche, M., Pieters, A., Marrero, J. F., Clavijo, S., et al. (2017). "Food security and nutrition in Venezuela," in Food and Nutrition Security in the Americas. Mexico: Ed. Interamerican Network of Academies of Sciences.

Trading Economics (2021). Venezuela Food Inflation. Available online at: https:// tradingeconomics.com/venezuela/food-inflation\#: :text=Looking\%20forward $\% 2 \mathrm{C} \% 20$ we $\% 20$ estimate $\% 20$ Food, according\%20to\%20our\%20econometric \%20models (accessed February 5, 2021).

Universidad Católica Andrés Bello (UCAB) (2020). Encuesta Nacional de Condiciones de Vida (ENCOVI) 2019-2020. Available online at: https://www. proyectoencovi.com/informe-interactivo-2019 (accessed August 1, 2020).

World Food Program (WFP) (2019). Venezuela Food Security Assessment. Main Findings. Available on line at: https://reliefweb.int/report/venezuelabolivarian-republic/wfp-venezuela-evaluaci-n-de-seguridad-alimentariaprincipales (accessed February 24, 2020). 
Conflict of Interest: The author declares that the research was conducted in the absence of any commercial or financial relationships that could be construed as a potential conflict of interest.

The reviewer AC declared a shared affiliation, though no collaboration, with the author.
Copyright (C) 2021 Rodríguez García. This is an open-access article distributed under the terms of the Creative Commons Attribution License (CC BY). The use, distribution or reproduction in other forums is permitted, provided the original author(s) and the copyright owner(s) are credited and that the original publication in this journal is cited, in accordance with accepted academic practice. No use, distribution or reproduction is permitted which does not comply with these terms. 